\title{
Consequences and Influence of Loads That Are Not contemplated In the Structure Calculation Process In some regulations.
}

\author{
Gil Carrillo, Francisco *, Mas-Guindal, Antonio José ** \\ * (Polytechnic University of Madrid. ETSEM, Spain. \\ ** (Polytechnic University of Madrid. ETSAM, Spain
}

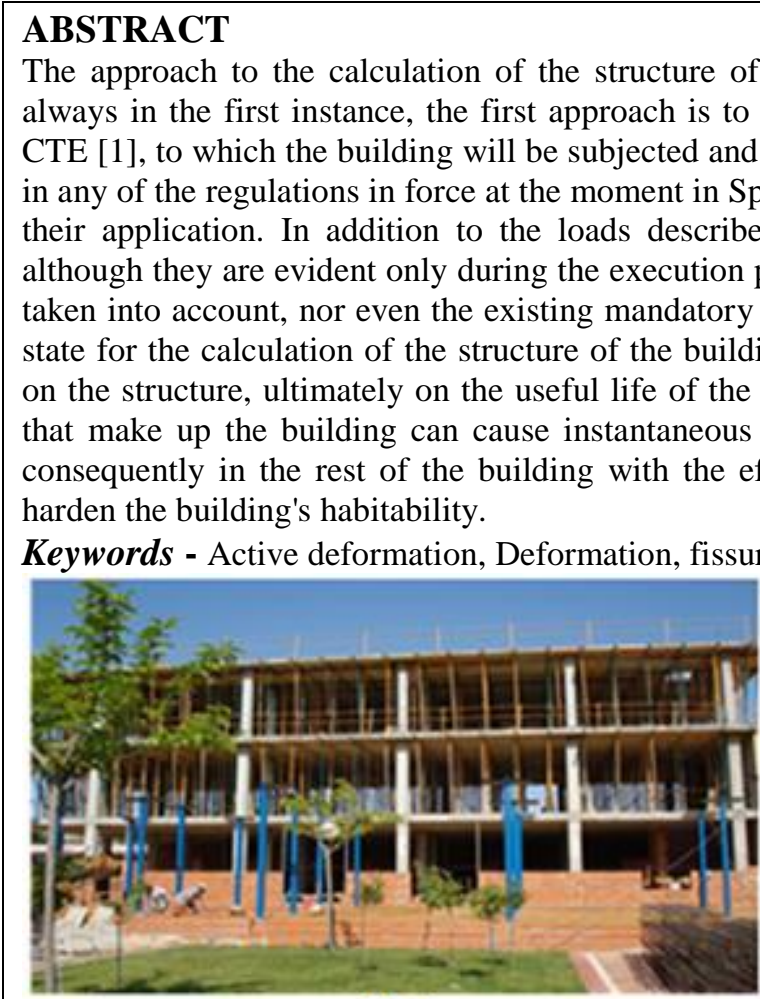

Fig. 1

\section{INTRODUCTION}

The nonobservance of loads that you have the concrete structures in the construction process, can generate permanent deformations[2] in the slabs of the structures that cannot be corrected later and will have as a consequence the habitability of the stay in it that has been Produced that excessive deformation[3]. The purpose of this investigation has been that the authorities that write the rules have to consider this phenomenon and impose the necessary measures so that it does not happen, the contribution that occurs to the scientific community is clear is the saving of later lawsuits Judicial proceedings with the economic costs entailed by claims to compensate the injured party.

\section{METHODOLOGY.}

2.1 Detection of loads the first action was the detection of possible loads that are not contemplated in the calculation process and that really intervene during the construction process. Table 1

It is well known that during the execution process the structure of a six-storey building when the work rhythms are imposed it is usual that when two forges are executed and the third and fourth ones are being executed, in order to reduce execution times They begin to release the elements that make up the formwork approximately when the forge has between 15 and 21 days depending on the size of the same and the weather. 
Table 1. Relationship of additional loads and their value, pallet loads

\begin{tabular}{|c|c|c|c|}
\hline $\begin{array}{c}\text { SYSTEM } \\
\text { STRUCTUREL }\end{array}$ & $\begin{array}{l}\text { Weight } \\
\text { per } \\
\text { unit of } \\
\text { brick }\end{array}$ & $\begin{array}{c}\text { Number } \\
\text { of } \\
\text { bricks } \\
\text { per } \\
\text { pallet }\end{array}$ & $\begin{array}{c}\text { Weight } \\
\text { of a } \\
\text { pallet of } \\
1 \times 1 \mathrm{~m} .\end{array}$ \\
\hline $\begin{array}{c}\text { Double hollow } \\
\text { ceramic bricks } \\
(24.3 \times 10.8 \times 7.9 \\
\mathrm{cm})\end{array}$ & $\begin{array}{l}1,70 \\
\mathrm{~kg}\end{array}$ & 384 & $\begin{array}{c}652,80 \\
\mathrm{~kg}\end{array}$ \\
\hline $\begin{array}{l}\text { Solid ceramic } \\
\text { bricks } \\
(25 \times 12 \times 6 \mathrm{~cm})\end{array}$ & $\begin{array}{c}2,65 \\
\mathrm{~kg}\end{array}$ & 480 & $\begin{array}{c}1.272,00 \\
\mathrm{~kg}\end{array}$ \\
\hline $\begin{array}{c}\text { Fresh mortar } \\
\text { hopper }\end{array}$ & $0.5 \mathrm{~m} 3$ & $\begin{array}{r}2000 \\
\mathrm{~kg} / \mathrm{m} 3\end{array}$ & $\begin{array}{c}1.000 \\
\mathrm{~kg} / \text { tolva }\end{array}$ \\
\hline
\end{tabular}

tolva: mortar diving container

From this moment on, the oldest slabs released from their formwork elements are being used for the collection of materials and to start new work cuts such as masonry, consequently they begin to accumulate materials in the edges of the slabs, Not forgetting that the resistance of these to the 21 days still has not reached the optimum resistance of project being around 90\% [2]. These loads that are generated in the borders of the slabs would have to identify them and evaluate them since they are going to act On the structure producing in it non-benign effects, but appropriate precautionary measures are taken, which would imply negative effects on the built structure as they could be permanent irreversible deformations that will influence the useful life and habitability of the building. The identification of the loads goes through a simple analysis of the construction process, one of the first loads that are generated would be the materials that make up the formwork system well it is true that this material not only stacks at the edges but in The inside of the surface of the newly stripped slab.

This material is composed of struts, coastal, you blow, bottoms and other small auxiliary material.

The first and most important load generated in the construction process are the pallets of material Figure 2 and specifically the brick pallets with which to start the basic masonry cuttings.

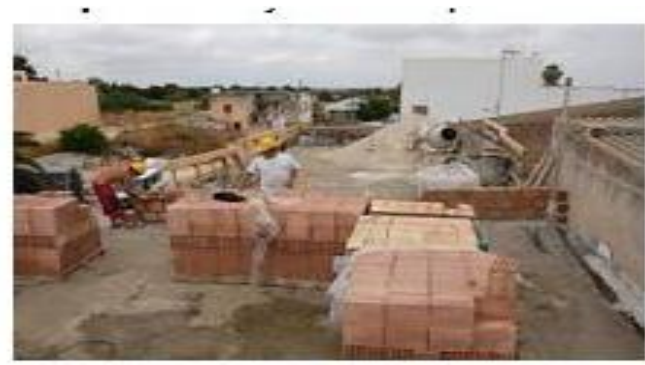

Fig. 2
It is interesting to mention that the construction sector is full of topics or unintentional bad arts that is to say of endemic evils continuous by costumes in the sector, in this case we are referring to the execution.

Of the divisions of the spaces with brick factories beginning to execute them by the lower plants and not by the highest ones as some authors recommend [2]-[3]. We agree that the safest execution is starting with the highest floor, so that when the partition of the lower floor is constructed, the upper floor will already have been deformed and the factory will be executed to the proper height so as not to have any damages in it Due to the active deformation. This criterion is not shared by the construction agents called by the LOE "the builders" because according to them delays the rates of progress in the development of the building, while justifying the need for the current praxis in almost all builders to start the Construction of the partition walls by the lower floors generating the building serious problems in the structure[4][7] emanating loads not evaluated or taken into account in the calculation of its structure and taking precautionary measures appropriate to this praxis that is to hold gasket and elastic joint .

The second non-evaluated load generating element is the fresh mortar hoppers [5] supplied on site since they are necessary for the construction of the mills, these hoppers are generally placed in the perimeters of the slabs because the auxiliary elements such as the cranes It has no maneuverability to leave it further from the edge of the floor.

\section{ASSESSMENT OF LOADS.}

Once the loads are detected, they are evaluated and quantified. Of the loads due to the collection of materials the first and one of the most important that we are going to study is the one originated by the brick pallets and mortar hopper, that is to say, the 1 st and 2nd classified in the previous epigraph.

If the stage of execution of a work is analyzed, the pallets that are to be stacked at first will be of double hollow bricks and solid brick bricks, some for the distribution of the different rooms of the houses, and the others for The separation of different houses, lifts and lifts, as the latter are dangerous areas during the work process because it can produce falls at different levels between plants because the holes are integrated into the plant and become familiar to operators. That confidence or familiarity can lead to the accident, with very serious consequences, because of this, apart from putting the protective measures that will be reflected in a safety plan. Of the first cuts that are made of masonry, is the enclosure of the enclosure 
of the elevator shaft and ladder core, this will be realized with $1 / 2$ foot of factory of solid ceramic brick rough $(25 \times 12 \times 6 \mathrm{~cm})$.

Once an estimate of the value of the pallet weights that can be collected at the edge of the structure, Table 1, is applied, one of these assumptions is applied to the specimen beam we analyzed, using the spreadsheet, Table $\mathrm{c}$, designed to doc. According to EHE-08[1] already used throughout the study and later the results of the resulting deformation in the three stages of time, that is to say to the 15,21 , and 28 days of the concreting with the increase of additional load of the pale of The materials collected taking as a value the minimum of Table 1 and impacting it in the beam of the porch under study.

\section{CALCULATION OF THE} STRUCTURE WITH THE LOADS.

Calculation of the structure with the loads. The calculation of the structure has been carried out by adding the additional loads listed in Table 1, the calculation or checking has been done using the model spreadsheet programmed by the author, and based on the parameters of the current EHE-08, With three calculation hypotheses at 15 days, 21 days and 28 days, after including the value of the additional charges not included in the standard.

\section{RESULT AND DISCUSSION}

Based on the results obtained using the model spreadsheet programmed by the author, with the three calculation hypotheses, at 15 days, 21 days and 28 days, after including the value of the additional charges not included in.

Table 2.Value deformation active with additional loads

\begin{tabular}{|c|c|c|c|}
\hline $\begin{array}{c}\text { Structural } \\
\text { porticoes } \\
11 \text { PILAR } \\
7-8\end{array}$ & $\begin{array}{c}\text { Deformation } \\
\text { no loads of } \\
\text { stock in } \\
(\mathrm{mm}) \text { Situation } \\
1 \\
\end{array}$ & $\begin{array}{l}\text { Deformation } \\
\text { With loads of } \\
\text { collections in } \\
(\mathrm{mm}) \text { Situation } \\
2 \\
\end{array}$ & $\begin{array}{l}\% \text { Active } \\
\text { Deformation } \\
\text { increase } \\
\text { from } 1 \text { to } \\
2(\mathrm{~mm})\end{array}$ \\
\hline $\begin{array}{c}\text { HA- } 22,50 \\
(15 \\
\text { Days) }\end{array}$ & 32,58 & 37,95 & $+16,48 \%$ \\
\hline $\begin{array}{c}\text { HA- } 23,75 \\
(21 \\
\text { Days) }\end{array}$ & 23.91 & 27,24 & $+13,93 \%$ \\
\hline $\begin{array}{c}\text { HA-25 } \\
(28 \\
\text { Days) }\end{array}$ & 21,93 & 25,54 & $+16,46 \%$ \\
\hline
\end{tabular}

\section{CONCLUSION.}

The conclusions reached after analyzing the results can be verified the increase of the active deformation that occurs when going from the status of charges situation 1 according to table 2, to situation 2, the increase that occurs becomes of Up to $16.46 \%$ of the initial value between the two situations. Grafhicl, in this graphic is also represented the permitted legal deformation of 10 $\mathrm{mm}$ in continuous line.

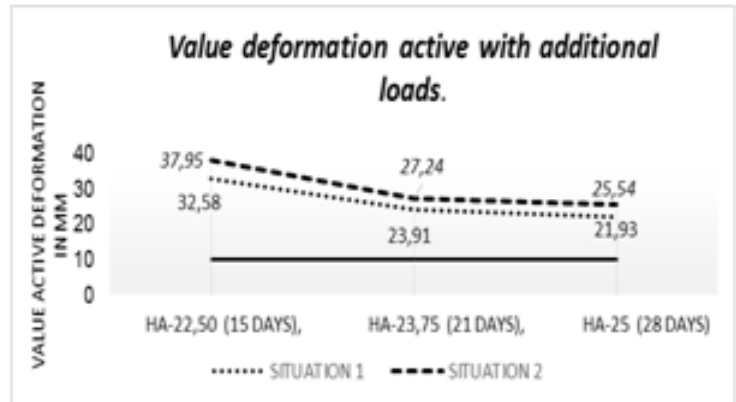

Graphics 1. Value deformation active with additional loads

These results have been obtained without taking into account the law of D`Alembert (1), [6] if this was done, the value of the deformations obtained would have increased by $23 \%$, a fact verified by the author. (1) Expression of D'Alembert

$P=W+\sqrt{W^{2}+\frac{2 W * h * A * E}{L}}=W\left(1+\sqrt{1+\frac{2 * h * A * E}{W * L}}\right)$

By studying one of its particular cases, it transforms a dynamic load into a static one, resulting in a dynamic load being transformed into a static and whose value at least doubles. If you take into account that a pallet with material is uploaded to the various slabs by means of auxiliary means, such as a tower crane or a car crane, the gruist, will almost never have a perfect view of the disembarkation of the materials always leaving it from a Height even if it is minimal, this will immediately imply the transformation of a static load into a dynamic one, taking the value of the weight of the brick plow twice the original load. Grafhic 2. In this graphic is also represented the permitted legal deformation of $10 \mathrm{~mm}$ in continuous line.

Table 3.Active deformation value with additional loads

Of $5 \mathrm{kN} / \mathrm{m}$. at $\mathrm{h}=20 \mathrm{~cm}=>10 \mathrm{kN} / \mathrm{m}$.

\begin{tabular}{|c|c|c|c|}
\hline $\begin{array}{c}\text { Structural } \\
\text { porticoes } \\
11 \text { PILAR } \\
7-8\end{array}$ & $\begin{array}{c}\text { Active } \\
\text { deformation } \\
\text { No loads of } \\
\text { stock in } \\
\text { (mm) } \\
\text { Situation } 1\end{array}$ & $\begin{array}{c}\text { Active } \\
\text { deformation } \\
\text { With loads } \\
\text { of } \\
\text { collections } \\
\text { in (mm) } \\
\text { Situation } 2\end{array}$ & $\begin{array}{c}\% \text { Active } \\
\text { deformation } \\
\text { increment } \\
\text { from } 1 \text { to } 2 \\
(\mathrm{~mm})\end{array}$ \\
\hline $\begin{array}{c}\text { HA- } 22,50 \\
\text { (15 } \\
\text { Days) }\end{array}$ & 32,58 & 42,20 & $+23 \%$ \\
\hline $\begin{array}{c}\text { HA- } 23,75 \\
(21 \\
\text { Days) }\end{array}$ & 23,91 & 27,48 & $+13 \%$ \\
\hline $\begin{array}{c}\text { HA-25 } \\
(28 \\
\text { Days) }\end{array}$ & 21,93 & 28,94 & $+24 \%$ \\
\hline
\end{tabular}




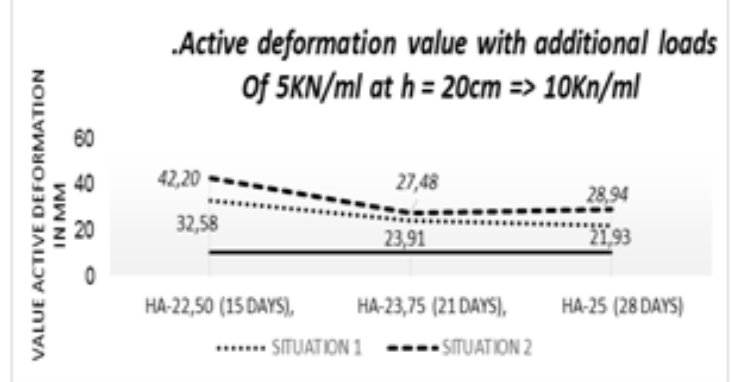

GRAPHICS 2. Value deformation active with additional loads

\section{REFERENCES}

[1] Norma EHE-08. / Real Decreto 1247/2008, de 18 de julio, por el que se aprueba la Instrucción de Hormigón Estructural. Ministerio de la Presidencia.

[2] Gil Carrillo, F. (2013). "Análisis crítico de la flecha de servició en las estructuras adinteladas de hormigón armado". Tesis Doctoral, Universidad Camilo José Cela, Madrid, España. Dirigida por Mas-Guindal Lafarga A.J.
[3] M Calavera J., García Dutari, L., y Rodríguez Escribano, R./Cálculo de flechas en estructuras de hormigón armado/ Intemac S.A. 2009 Madrid.

[4] Mas-Guindal Lafarga A.J. (1981). "Las grietas en las estructuras de fábrica. $\mathrm{N}^{\circ} 446$ (Noviembre/diciembre 1996) Informes de la Construcción. Mayo 1982.

[5] Julio José Vaquero en "LA EHE Explicada por sus autores, ISBN 84-95560-00-3, Leynfor Siglo XXI,S.A,2000.

[6] Jean-Baptiste le Rondd'Alembert (16 November 1717 - 29 October 1783) was a French mathematician, mechanician, physicist.

\section{Theses:}

[7] Mas-Guindal Lafarga A.J. (1981) "Sistemas Planos. Aproximación al modelo de análisis de piezas rectas de hormigón armado en estado último" Tesis Doctoral oa.upm.es. $\mathrm{N}^{\circ}$ 340 (Mayo 1982) Informes de la Construcción. 